\title{
Endogenous Hydrogen Sulfide Enhances Cell Proliferation of Human Gastric Cancer AGS Cells
}

\author{
Fumiko Sekiguchi, Teruki Sekimoto, Ayaka Ogura, and Atsufumi Kawabata* \\ Laboratory of Pharmacology and Pathophysiology, Faculty of Pharmacy, Kindai University; 3-4-1 Kowakae, \\ Higashi-Osaka 577-8502, Japan. \\ Received December 14, 2015; accepted January 26, 2016
}

\begin{abstract}
Hydrogen sulfide $\left(\mathrm{H}_{2} \mathrm{~S}\right)$, the third gasotransmitter, is endogenously generated by certain $\mathrm{H}_{2} \mathrm{~S}$ synthesizing enzymes, including cystathionine- $\gamma$-lyase (CSE) and cystathionine- $\beta$-synthase (CBS) from L-cysteine in the mammalian body. Several studies have shown that endogenous and exogenous $\mathrm{H}_{2} \mathrm{~S}$ affects the proliferation of cancer cells, although the effects of $\mathrm{H}_{2} \mathrm{~S}$ appear to vary with cell type, being either promotive or suppressive. In the present study, we determined whether endogenously formed $\mathrm{H}_{2} \mathrm{~S}$ regulates proliferation in human gastric cancer AGS cells. CSE, but not CBS, was expressed in AGS cells. CSE inhibitors, DL-propargylglycine (PPG) and $\beta$-cyano-L-alanine (BCA), significantly suppressed the proliferation of AGS cells in a concentration-dependent manner. CSE inhibitors did not increase lactate dehydrogenase (LDH) release in the same concentration range. The inhibitory effects of PPG and BCA on cell proliferation were reversed by repetitive application of NaHS, a donor of $\mathrm{H}_{2} \mathrm{~S}$. Interestingly, nuclear condensation and fragmentation were detected in AGS cells treated with PPG or BCA. These results suggest that endogenous $\mathrm{H}_{2} \mathrm{~S}$ produced by CSE may contribute to the proliferation of gastric cancer AGS cells, most probably through anti-apoptotic actions.
\end{abstract}

Key words hydrogen sulfide; cystathionine- $\gamma$-lyase (CSE); cell proliferation; gastric cancer AGS cell; antiapoptotic effect

Hydrogen sulfide $\left(\mathrm{H}_{2} \mathrm{~S}\right)$ is a colorless and highly watersoluble gas with irritant smell like rotten eggs contained in the volcanic gas. Although atmospheric $\mathrm{H}_{2} \mathrm{~S}$ gas is toxic and lethal at concentrations higher than $500 \mathrm{ppm},{ }^{1)} \mathrm{H}_{2} \mathrm{~S}$ is now considered the third gasotransmitter after nitric oxide (NO) and carbon monoxide (CO). ${ }^{2)}$ In the mammalian tissues, $\mathrm{H}_{2} \mathrm{~S}$ is endogenously synthesized from L-cysteine by enzymes including cystathionine- $\gamma$-lyase (CSE), cystathionine- $\beta$-synthase (CBS) and 3-mercaptopyruvate sulfurtransferase (3MST) with cysteine aminotransferase (CAT). ${ }^{2,3}$ It has been reported that endogenous $\mathrm{H}_{2} \mathrm{~S}$ is involved in various physiological/ pathophysiological responses, e.g. long-term synaptic potentiation, blood vessel relaxation, cardioprotection, inhibition of platelet aggregation, cell viability change, inflammation, pain sensation, etc. $\left.{ }^{2,4}-7\right) \mathrm{H}_{2} \mathrm{~S}$ appears to play a dual role in cell viability, being cytoprotective and cytotoxic depending on cell types. ${ }^{2,6,8)}$ In the stomach, however, endogenous and exogenous $\mathrm{H}_{2} \mathrm{~S}$ may be primarily protective against mucosal injury. ${ }^{8-11)}$ We have reported that NaHS, an $\mathrm{H}_{2} \mathrm{~S}$ donor, exhibits a cytoprotective effect against oxidative stress in the gastric mucosa. ${ }^{8)}$ In addition, Wallace et $a l .{ }^{11)}$ have reported that endogenous $\mathrm{H}_{2} \mathrm{~S}$ produced by CSE in the gastric mucosa acts to promote ulcer healing. On the other hand, there are inconsistent papers concerning the effects of $\mathrm{H}_{2} \mathrm{~S}$ on gastric cancer cell proliferation and related angiogenesis. ${ }^{12,13)}$ In the present study, we evaluated the role of endogenous $\mathrm{H}_{2} \mathrm{~S}$ in gastric cancer proliferations in human gastric cancer AGS cells. Our results showed that endogenous $\mathrm{H}_{2} \mathrm{~S}$ synthesized by CSE promotes the proliferation of AGS cells, most probably through inhibition of apoptosis.

\section{MATERIALS AND METHODS}

Chemicals DL-Propargylglycine (PPG) and $\beta$-cyano-Lalanine (BCA) were purchased from Sigma-Aldrich (St. Louis, MO, U.S.A.), and NaHS was from Kishida Chemical (Osaka, Japan).

Cell Culture Human gastric adenocarcinoma AGS cells were purchased from Sumitomo Dainippon Pharma (Osaka, Japan) and cultured in glucose-containing RPMI-1640 (Wako Pure Chemical Industries, Ltd., Osaka, Japan) supplemented with $10 \%$ fetal calf serum (FCS; Thermo Electron, Melbourne, Australia), $100 \mathrm{U} / \mathrm{mL}$ penicillin and $100 \mu \mathrm{g} / \mathrm{mL}$ streptomycin (Gibco, Carlsbad, CA, U.S.A.) in a $5 \% \mathrm{CO}_{2}$ incubator at $37^{\circ} \mathrm{C}$.

3-(4,5-Dimethylthiazol-2-yl)-2,5-diphenyltetrazolium Bromide (MTT) Assay AGS cells $\left(2 \times 10^{3}\right.$ cells/well) were seeded in 96-well plates in the culture medium mentioned above and cultured for one day. Then, CSE inhibitors were added and further cultured for $48 \mathrm{~h}$. The cell number was determined by using a MTT cell proliferation kit (Cayman Chem., Ann Arbor, MI, U.S.A.). NaHS, an $\mathrm{H}_{2} \mathrm{~S}$ donor, at $1.5 \mathrm{~mm}$ was repetitively applied at $0,12,24$ and $36 \mathrm{~h}$ after the addition of CSE inhibitors. The data are represented as the percentage of the cell numbers just before the addition of CSE inhibitors.

Lactate Dehydrogenase (LDH) Release Assay Forty eight hours after the addition of CSE inhibitors, the activity of LDH released from the cells into the culture medium was measured with an LDH cytotoxicity detection kit (TaKaRa Bio, Otsu, Japan). The activity of released LDH was standardized by the total amount of LDH in the cells, which was obtained by determining the LDH activity from the cells lysed with 1\% Triton X-100 (Kishida Chemical). The data are represented as the percentage of the levels of LDH activity just 
A

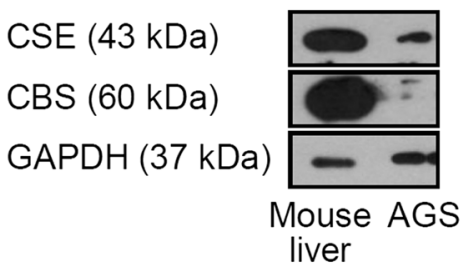

B

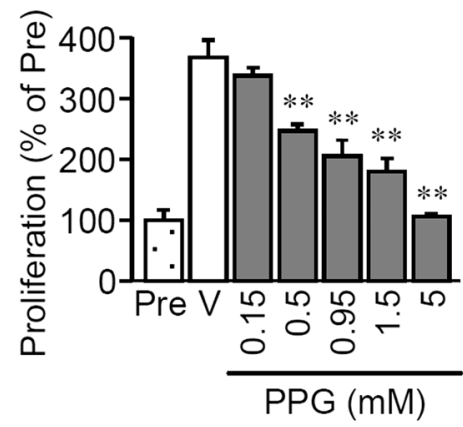

D

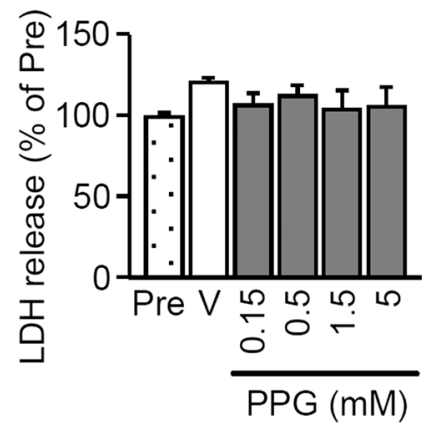

C

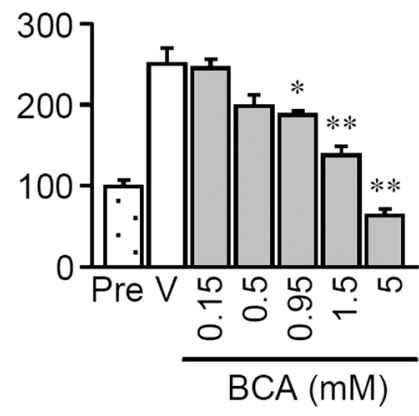

E

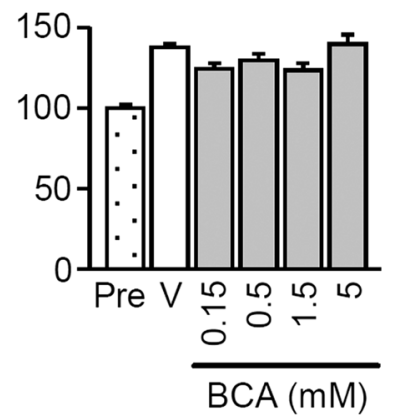

Fig. 1. Effect of Cystathionine- $\gamma$-lyase (CSE) Inhibitors, DL-Propargylglycine (PPG) and $\beta$-Cyano-L-alanine (BCA), on Cell Proliferation of AGS Cells

(A) Detection of protein expression of CSE, but not cystathionine- $\beta$-synthase (CBS), in AGS cells. Mouse liver is used as a positive control. (B-E) Cell proliferation and cell damage assessed by the MTT method $(B, C)$ and released LDH activity (D, E), respectively, were determined $48 \mathrm{~h}$ after addition of CSE inhibitors. Note that both CSE inhibitors suppressed cell proliferation $(\mathrm{B}, \mathrm{C})$ without cell damage $(\mathrm{D}, \mathrm{E})$. Data show the mean \pm S.E.M. from $8(\mathrm{~B}, \mathrm{C})$ or $4(\mathrm{D}, \mathrm{E})$ experiments. ${ }^{*} p<0.05, * * p<0.01$, vs. vehicle $(\mathrm{V})$.

before the addition of CSE inhibitors.

Hoechst 33258 Staining for Detection of Apoptosis AGS cells $\left(1.5 \times 10^{5}\right.$ cells) were seeded in 6 -well plates and cultured for one day. After 48-h incubation with CSE inhibitors, cells were harvested with a cell scraper, fixed in phosphate buffered saline (PBS) containing 1\% glutaraldehyde for $30 \mathrm{~min}$ at room temperature, and then, stained with Hoechst 33258 (Wako Pure Chemical Industries, Ltd.). A drop of the cell suspension was placed on a slide glass and covered with a coverslip. The nuclear condensation and fragmentation of the cells were morphologically evaluated under UV excitation light with an inverted fluorescence microscope (BX50; Olympus, Tokyo, Japan). The cells with nuclear condensation and fragmentation were counted, and the results are expressed as the percentage of total cells (the proportion of apoptotic cells).

Western Blotting AGS cells $\left(1.2 \times 10^{6}\right.$ cells/dish $)$ were seeded in $100 \mathrm{~mm}$ culture dishes and cultured for one day. The cells were lysed in sodium dodecyl sulfate (SDS) buffer $(2 \%$ SDS, $62.5 \mathrm{~mm}$ Tris- $\mathrm{HCl}$ and $10 \%$ glycerol, $\mathrm{pH} 6.8$ ). The protein sample was separated by electrophoresis on $12.5 \%$ SDSpolyacrylamide gels (Wako Pure Chemical Industries, Ltd.), and transferred onto polyvinylidene difluoride membrane
(Millipore, Bedford, MA, U.S.A.). Primary antibodies used in the present study were: rabbit anti-CSE polyclonal antibody (Sigma-Genosys/Sigma-Aldrich) against a peptide corresponding to the amino acid sequence, (C)80GGTNRYFRR89V, in rat $\mathrm{CSE},{ }^{14)}$ mouse $\mathrm{CBS}$ monoclonal antibody (clone 3E1; Abnova Co., Taipei, Taiwan) and rabbit anti-glyceraldehyde3-phosphate dehydrogenase (GAPDH) polyclonal antibody (sc-25778; Santa Cruz Biotechnol., Santa Cruz, CA, U.S.A.). We used the polyclonal antibody against rat CSE in the present study, because we have accumulated evidence that this antibody specifically recognizes not only rat and mouse CSE, ${ }^{15,16)}$ but also human CSE. ${ }^{17)}$ On the other hand, we used the monoclonal antibody against human CBS, the specificity of which was confirmed in our recent study. ${ }^{17)}$ After washing the primary antibodies, the membrane was then incubated with horseradish peroxidase (HRP)-conjugated anti-rabbit or anti-mouse antibodies (Cell Signaling Technol., Beverly, MA, U.S.A.). Immunolabelled proteins were visualized by ChemiLumi One Super (Nacalai Tesque, Kyoto, Japan). The protein sample of mouse liver homogenate was used as positive control for CSE and CBS.

Statistics Data are represented as mean \pm standard error 
A

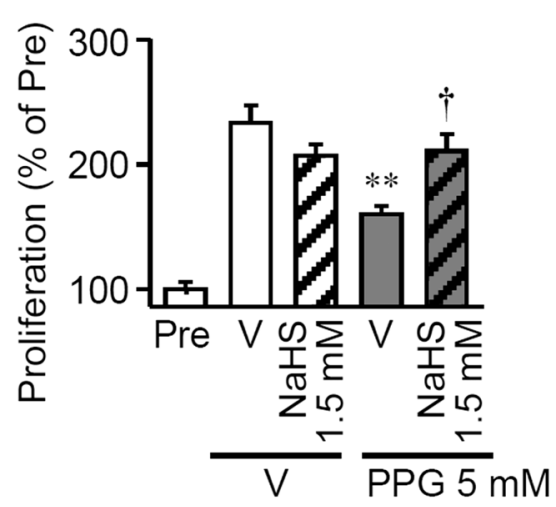

B

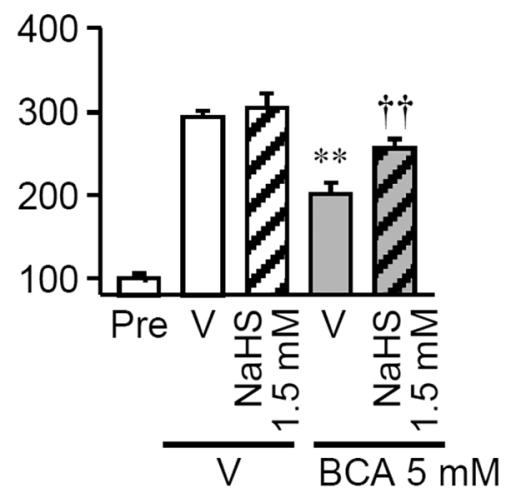

Fig. 2. Effect of Repetitive Addition of NaHS, an $\mathrm{H}_{2} \mathrm{~S}$ Donor, on the Inhibitory Effect of CSE Inhibitors, PPG and BCA, on Proliferation of AGS Cells

NaHS at $1.5 \mathrm{~mm}$ was repetitively added $0,12,24$ and $36 \mathrm{~h}$ to the cells after addition of CSE inhibitors. Cell proliferation was determined $48 \mathrm{~h}$ after addition of the CSE inhibitors. Data show the mean \pm S.E.M. from 16 (A), 16-24 (B) experiments. ${ }^{* *} p<0.01 v s$. V+V. ${ }^{\dagger} p<0.05,{ }^{\dagger} p<0.01 v s$. V+PPG or BCA. V, vehicle; PPG, DL-propargylglycine; BCA, $\beta$-cyano-L-alanine.

of the mean (S.E.M.). Statistical significance was evaluated by ANOVA followed by Tukey's test. Significance was set at a level of $p<0.05$.

\section{RESULTS AND DISCUSSION}

Protein expression of CSE, but not CBS, was detected in AGS cells (Fig. 1A). Cell proliferation of AGS cells for $48 \mathrm{~h}$ was suppressed by CSE inhibitors, DL-propargylglycine (PPG) and $\beta$-cyano-L-alanine (BCA), in a concentration-dependent manner (Figs. 1B, C). The suppressive effects of PPG and BCA were significant $0.5-5$ and $0.95-5 \mathrm{~mm}$, respectively. CSE inhibitors in the same range of the concentrations did not increase LDH release from the cells (Figs. 1D, E), indicating that these CSE inhibitors suppressed the cell proliferation without causing cell death. To determine whether endogenous $\mathrm{H}_{2} \mathrm{~S}$ synthesized by CSE actually contributes to the proliferation of AGS cells, effects of NaHS, an $\mathrm{H}_{2} \mathrm{~S}$ donor, on the inhibitory effects of PPG and BCA on proliferation were examined. Repetitive application of NaHS significantly reversed the suppression of proliferation by PPG and BCA (Fig. 2). Both PPG and BCA significantly increased proportion of apoptotic cells with nuclear condensation and fragmentation, as assessed by the Hoechst 33258 staining (Fig. 3).

Our data suggest that the proliferation of human gastric cancer AGS cells is enhanced by the endogenous $\mathrm{H}_{2} \mathrm{~S}$ synthesized by CSE, which exhibits anti-apoptotic activity. CBS is not considered responsible for $\mathrm{H}_{2} \mathrm{~S}$ production in AGS cells, since the protein expression of CBS was hardly detected in AGS cells (Fig. 1A). It has been reported that the increased $\mathrm{H}_{2} \mathrm{~S}$ production plays a crucial role in cell proliferation and the related angiogenesis in several types of cancer cell lines, such as colonic and ovarian cancers. ${ }^{18,19)}$ In addition, there are many papers showing that endogenous or exogenous $\mathrm{H}_{2} \mathrm{~S}$ modulates cell proliferation and migration in gastric, oral, breast, pancreas, lung or prostate cancer and also leukemia, ${ }^{12,20-22)}$ whereas, $\mathrm{H}_{2} \mathrm{~S}$ promotes and suppresses cancer growth in distinct cells. Thus, the effects of $\mathrm{H}_{2} \mathrm{~S}$ on cancers might vary with the tissues, conditions surrounding cancer, the amount of synthesized $\mathrm{H}_{2} \mathrm{~S}$, and so on.

Our data suggest the involvement of anti-apoptotic effect of
A

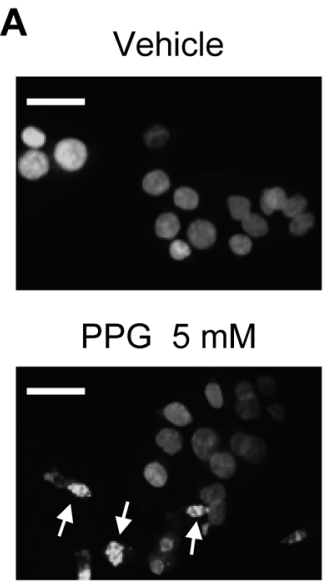

B

Fig. 3. Increase in Apoptotic Cells by CSE Inhibitors, PPG and BCA, in AGS Cells, as Assessed by Staining with Hoechst 33258

(A) Arrows indicate cells with nuclear condensation and fragmentation, namely apoptotic cells. Scale bar; $50 \mu \mathrm{m}$. (B) Data show the mean \pm S.E.M. from 4 experiments. $* * p<0.01$ vs. V. PPG, DL-propargylglycine; BCA, $\beta$-cyano-L-alanine; $\mathrm{V}$, vehicle.

$\mathrm{H}_{2} \mathrm{~S}$ in the enhancement of cell proliferation via the $\mathrm{CSE} / \mathrm{H}_{2} \mathrm{~S}$ pathway (Fig. 3). It has been reported that $\mathrm{H}_{2} \mathrm{~S}$ enhances the activity of nuclear factor kappaB (NF- $\kappa \mathrm{B})$ through the sulfhydration of the p65 subunit, leading to anti-apoptotic transcriptional activity. ${ }^{23)}$ The $\mathrm{H}_{2} \mathrm{~S} / \mathrm{NF}-\kappa \mathrm{B} /$ anti-apoptotic pathway might contribute to the $\mathrm{H}_{2} \mathrm{~S}$-mediated increase in proliferation of AGS cells. On the other hand, our group has reported that $\mathrm{H}_{2} \mathrm{~S}$ enhances the function of $\mathrm{Ca}_{\mathrm{v}} 3.2 \mathrm{~T}$-type calcium channels. ${ }^{5,24,25)}$ In addition, an independent group has reported the contribution of $\mathrm{Ca}_{\mathrm{v}} 3.2$ to the cell proliferation of prostate cancer LNCaP cells. ${ }^{26)}$ However, the $\mathrm{H}_{2} \mathrm{~S} / \mathrm{Ca}_{\mathrm{v}} 3.2$ pathway is not considered to be involved in the $\mathrm{H}_{2} \mathrm{~S}$-mediated proliferation of AGS cells, because we could not detect the T-type calcium channel-dependent currents in AGS cells by the whole cell patch clamp technique (data not shown). Further studies are needed to clarify the target molecules of $\mathrm{H}_{2} \mathrm{~S}$ for the $\mathrm{H}_{2} \mathrm{~S}$ mediated proliferation in future.

Acknowledgments This research was supported in part by Grant-in-Aid for Scientific Research (C) Number 23590122 
from Japan Society for the Promotion of Science, 2011-2013, and also by the MEXT-Supported Program for the Strategic Research Foundation at Private Universities, 2014-2018 (S1411037).

Conflict of Interest The authors declare no conflict of interest.

\section{REFERENCES}

1) Dorman DC, Moulin FJ, McManus BE, Mahle KC, James RA, Struve MF. Cytochrome oxidase inhibition induced by acute hydrogen sulfide inhalation: correlation with tissue sulfide concentrations in the rat brain, liver, lung, and nasal epithelium. Toxicol. Sci., 65, 18-25 (2002).

2) Wang R. Physiological implications of hydrogen sulfide: a whiff exploration that blossomed. Physiol. Rev., 92, 791-896 (2012).

3) Kimura H. Hydrogen sulfide: its production, release and functions. Amino Acids, 41, 113-121 (2011).

4) Li L, Moore PK. Putative biological roles of hydrogen sulfide in health and disease: a breath of not so fresh air? Trends Pharmacol. Sci., 29, 84-90 (2008).

5) Kawabata A, Ishiki T, Nagasawa K, Yoshida S, Maeda Y, Takahashi T, Sekiguchi F, Wada T, Ichida S, Nishikawa H. Hydrogen sulfide as a novel nociceptive messenger. Pain, 132, 74-81 (2007).

6) Kurokawa Y, Sekiguchi F, Kubo S, Yamasaki Y, Matsuda S, Okamoto Y, Sekimoto T, Fukatsu A, Nishikawa H, Kume T, Fukushima N, Akaike A, Kawabata A. Involvement of ERK in NMDA receptor-independent cortical neurotoxicity of hydrogen sulfide. Biochem. Biophys. Res. Commun., 414, 727-732 (2011).

7) Nishikawa H, Hayashi H, Kubo S, Tsubota-Matsunami M, Sekiguchi F, Kawabata A. Inhibition by hydrogen sulfide of rabbit platelet aggregation and calcium mobilization. Biol. Pharm. Bull., 36, 1278-1282 (2013).

8) Yonezawa D, Sekiguchi F, Miyamoto M, Taniguchi E, Honjo M, Masuko T, Nishikawa H, Kawabata A. A protective role of hydrogen sulfide against oxidative stress in rat gastric mucosal epithelium. Toxicology, 241, 11-18 (2007).

9) Fiorucci S, Antonelli E, Distrutti E, Rizzo G, Mencarelli A, Orlandi S, Zanardo R, Renga B, Di Sante M, Morelli A, Cirino G, Wallace JL. Inhibition of hydrogen sulfide generation contributes to gastric injury caused by anti-inflammatory nonsteroidal drugs. Gastroenterology, 129, 1210-1224 (2005)

10) Li L, Rossoni G, Sparatore A, Lee LC, Del Soldato P, Moore PK. Anti-inflammatory and gastrointestinal effects of a novel diclofenac derivative. Free Radic. Biol. Med., 42, 706-719 (2007).

11) Wallace JL, Dicay M, McKnight W, Martin GR. Hydrogen sulfide enhances ulcer healing in rats. FASEB J., 21, 4070-4076 (2007).

12) Ma K, Liu Y, Zhu Q, Liu CH, Duan JL, Tan BK, Zhu YZ. $\mathrm{H}_{2} \mathrm{~S}$ donor, $S$-propargyl-cysteine, increases CSE in SGC-7901 and cancer-induced mice: evidence for a novel anti-cancer effect of endogenous $\mathrm{H}_{2} \mathrm{~S}$ ? PLOS ONE, 6, e20525 (2011).

13) Choi KS, Song H, Kim EH, Choi JH, Hong H, Han YM, Hahm KB. Inhibition of hydrogen sulfide-induced angiogenesis and inflammation in vascular endothelial cells: potential mechanisms of gastric cancer prevention by Korean red ginseng. J. Ginseng. Res., 36,
135-145 (2012).

14) Nishi N, Tanabe H, Oya H, Urushihara M, Miyanaka H, Wada F, Identification of probasin-related antigen as cystathionine gammalyase by molecular cloning. J. Biol. Chem., 269, 1015-1019 (1994).

15) Okubo K, Takahashi T, Sekiguchi F, Kanaoka D, Matsunami M, Ohkubo T, Yamazaki J, Fukushima N, Yoshida S, Kawabata A. Inhibition of T-type calcium channels and hydrogen sulfide-forming enzyme reverses paclitaxel-evoked neuropathic hyperalgesia in rats. Neuroscience, 188, 148-156 (2011).

16) Matsunami M, Miki T, Nishiura K, Hayashi Y, Okawa Y, Nishikawa H, Sekiguchi F, Kubo L, Ozaki T, Tsujiuchi T, Kawabata A. Involvement of the endogenous hydrogen sulfide/Ca 3.2 T-type $\mathrm{Ca}^{2+}$ channel pathway in cystitis-related bladder pain in mice. Br. J. Pharmacol., 167, 917-928 (2012).

17) Fukami K, Sekiguchi F, Yasukawa M, Asano E, Kasamatsu R, Ueda M, Yoshida S, Kawabata A. Functional upregulation of the $\mathrm{H}_{2} \mathrm{~S} / \mathrm{Ca}_{\mathrm{v}} 3.2$ channel pathway accelerates secretory function in neuroendocrine-differentiated human prostate cancer cells. Biochem. Pharmacol., 97, 300-309 (2015).

18) Szabo C, Coletta C, Chao C, Modis K, Szczesny B, Papapetropoulos A, Hellmich MR. Tumor-derived hydrogen sulfide, produced by cystathionine- $\beta$-synthase, stimulates bioenergetics, cell proliferation, and angiogenesis in colon cancer. Proc. Natl. Acad. Sci. U.S.A., 110, 12474-12479 (2013).

19) Hellmich MR, Coletta C, Chao C, Szabo C. The therapeutic potential of cystathionine $\beta$-synthetase/hydrogen sulfide inhibition in cancer. Antioxid. Redox Signal., 22, 424-448 (2015).

20) Chattopadhyay M, Kodela R, Nath N, Dastagirzada YM, Velazquez-Martinez CA, Boring D, Kashfi K. Hydrogen sulfide-releasing NSAIDs inhibit the growth of human cancer cells: a general property and evidence of a tissue type-independent effect. Biochem. Pharmacol., 83, 715-722 (2012).

21) Lee ZW, Teo XY, Tay EY, Tan CH, Hagen T, Moore PK, Deng LW. Utilizing hydrogen sulfide as a novel anti-cancer agent by targeting cancer glycolysis and $\mathrm{pH}$ imbalance. Br. J. Pharmacol., 171, 4322-4336 (2014).

22) Murata T, Sato T, Kamoda T, Moriyama H, Kumazawa Y, Hanada N. Differential susceptibility to hydrogen sulfide-induced apoptosis between PHLDA1-overexpressing oral cancer cell lines and oral keratinocytes: role of PHLDA1 as an apoptosis suppressor. Exp. Cell Res., 320, 247-257 (2014).

23) Sen N, Paul BD, Gadalla MM, Mustafa AK, Sen T, Xu R, Kim S, Snyder SH. Hydrogen sulfide-linked sulfhydration of NF- $\kappa$ B mediates its antiapoptotic actions. Mol. Cell, 45, 13-24 (2012).

24) Sekiguchi F, Miyamoto Y, Kanaoka D, Ide H, Yoshida S, Ohkubo T, Kawabata A. Endogenous and exogenous hydrogen sulfide facilitates T-type calcium channel currents in $\mathrm{Ca}_{\mathrm{v}} 3.2$-expressing HEK293 cells. Biochem. Biophys. Res. Commun., 445, 225-229 (2014).

25) Fukami K, Kawabata A. Hydrogen sulfide and neuronal differentiation: Focus on $\mathrm{Ca}^{2+}$ channels. Nitric Oxide, 46, 50-54 (2015).

26) Gackiére F, Warnier M, Katsogiannou M, Derouiche S, Delcourt P, Dewailly E, Slomianny C, Humez S, Prevarskaya N, Roudbaraki M, Mariot P. Functional coupling between large-conductance potassium channels and $\mathrm{Ca}_{\mathrm{v}} 3.2$ voltage-dependent calcium channels participates in prostate cancer cell growth. Biol. Open, 2, 941-951 (2013). 